\title{
Prevalence of metabolic disorders and effect on subsequent daily milk quantity and quality in Holstein cows
}

\author{
Vesna Gantner ${ }^{1}$, Tina Bobić ${ }^{2}$, and Klemen Potočnik ${ }^{3}$ \\ ${ }^{1}$ Department for Special Zootechnique, Faculty of Agriculture, University of Josip Juraj Strossmayer, \\ Kralja Petra Svačića 1d, 31000 Osijek, Croatia \\ ${ }^{2}$ Department for Animal Breeding, Faculty of Agriculture, University of Josip Juraj Strossmayer, \\ Kralja Petra Svačića 1d, 31000 Osijek, Croatia \\ ${ }^{3}$ Department of Animal Science, Biotechnical faculty, University of Ljubljana, \\ Groblje 3, SI-1230, Domžale, Slovenia \\ Correspondence to: Vesna Gantner (vgantner@pfos.hr)
}

Received: 3 June 2016 - Revised: 31 July 2016 - Accepted: 26 August 2016 - Published: 13 September 2016

\begin{abstract}
Aiming at the determination of the metabolic disorder prevalence as well as the effect of subclinical disorders on daily milk traits of Holsteins, over 1 million (1962 831) test day records were analysed. The metabolic disorder (ketosis or acidosis) prevalence was indicated by the fat-to-protein $(F / P)$ ratio, while subclinical disorder was indicated by the $F / P$ ratio and cows' daily production. The effect of subclinical disorders on daily milk traits was tested by Scheffe's method (SAS/STAT). The highest ketosis prevalence occurred in early lactation. In first-parity cows ketosis prevalence was highest in the first 15 days of lactation, while in cows in higher lactations, the prevalence peak occurred on the 25th day. A higher ketosis prevalence during the entire lactation was observed in multiparous cows compared to first-parity cows. Regarding the acidosis prevalence, high values were determined at the beginning of the lactation with a decreasing trend until mid-lactation, when the prevalence increased up to $22 \%$. The highest decrease in daily milk yield as a consequence of subclinical ketosis was determined as 4.21 and $3.72 \mathrm{~kg} \mathrm{day}^{-1}$ in first-parity cows and those with more than four lactations, respectively. A significant negative effect of subclinical acidosis on daily milk yield $\left(2.79 \mathrm{~kg} \mathrm{day}^{-1}\right)$ was highest in cows in the third lactation. A production decline in subsequent milk controls due to subclinical ketosis or acidosis in all cows was also determined. Subclinical disorders also significantly alter daily milk quality. This indicates that the test day records could be used as a cost-effective and non-invasive method for monitoring herd health.
\end{abstract}

\section{Introduction}

Efficient dairy cattle production requires gravidity and parturition each year. The transition from the pregnant, nonlactating state to the non-pregnant, lactating state is too frequently a stressful experience for the cow. LeBlanc (2010) observed that most of the metabolic disorders (up to $50 \%$ ) of dairy cows occur within the first 2 weeks of lactation. Dairy cows are predisposed to various disorders during the transition period as a result of a variety of factors, such as dietary changes, a negative energy balance, decreased feed intake, weight loss, hypocalcemia, etc. Also, cows can experience environmental stressors such as regrouping (Mulligan and Doherty, 2008) and inadequate climatic conditions (Broucek et al., 2007) and body condition score (BCS). One of the most common disorders in lactating dairy cows is ketosis as well as acidosis.

Ketosis is a metabolic disorder that can occur both in clinical and subclinical forms, where subclinical ketosis is defined as a preclinical stage of ketosis. Clinical ketosis most frequently occurs in high-producing cows between the second and seventh week after calving as a consequence of inad- 
Table 1. Basic statistics of daily milk traits according to parity.

\begin{tabular}{lccc|rcc|rc|r|rr|rr}
\hline \multirow{2}{*}{ Parity } & \multicolumn{3}{c|}{ DMY (kg) } & \multicolumn{3}{c|}{ DFC (\%) } & \multicolumn{3}{|c|}{ DPC (\%) } & \multicolumn{3}{c}{ FPR } \\
\cline { 2 - 12 } & Mean & SD & CV & Mean & SD & CV & Mean & SD & CV & Mean & SD & CV \\
\hline 1 & 21.5 & 7.3 & 33.7 & 4.0 & 0.9 & 23.3 & 3.3 & 0.4 & 12.2 & 1.2 & 0.3 & 23.7 \\
2 & 23.7 & 9.2 & 38.9 & 4.1 & 0.9 & 24.1 & 3.4 & 0.4 & 12.9 & 1.2 & 0.3 & 24.1 \\
3 & 23.8 & 9.5 & 39.9 & 4.1 & 1.0 & 24.2 & 3.3 & 0.4 & 13.0 & 1.2 & 0.3 & 24.7 \\
$4+$ & 22.1 & 8.9 & 40.5 & 4.1 & 0.9 & 24.1 & 3.3 & 0.4 & 13.2 & 1.3 & 0.3 & 24.6 \\
\hline \multirow{2}{*}{ Total } & 22.6 & 8.6 & 38.1 & 4.1 & 0.9 & 23.8 & 3.3 & 0.4 & 12.7 & 1.2 & 0.3 & 24.2 \\
\hline
\end{tabular}

DMY - daily milk yield; DFC - daily fat content; DPC - daily protein content; FPR - fat-to-protein ratio.

equate nutrition and management (Gillund et al., 2001). Ketosis prevalence could be influenced by a variety of factors, e.g., breed, parity, season and herd-related factors. Dohoo and Martin (1984) reported that the lactational risk of ketosis incidence was between 1.1 and $9.2 \%$, while Rajala-Schultz et al. (1999) determined an incidence risk of 2.5 and $4.2 \%$, depending on parity. Gustafsson and Emanuelson (1996) as well as Rajala-Schultz and Gröhn (1999) stated that clinical ketosis induces economic losses for the dairy farmer through treatment costs, decreased milk production, impaired reproduction efficiency and increased involuntary culling. Andersson (1988) stated that subclinical ketosis can be revealed by determining levels of plasma glucose, plasma non-esterified fatty acids (NEFAs), and milk or urine ketone body concentration.

In recent years, subacute ruminal acidosis (SARA) has become an increasing problem in well-managed, high-yielding dairy herds. Therefore, the monitoring of groups of cows for signs of SARA becomes crucial. In the USA, subacute ruminal acidosis has been reported to be prevalent in $19 \%$ of early-lactation and $26 \%$ of mid-lactation dairy cows. Bramley et al. (2005) and O'Grady et al. (2008) determined that between 10 and $15 \%$ of dairy cows grazing ryegrass-based pastures perennially have SARA. The highest rate of SARA was determined in early-lactating cows as well as in those at peak dry-matter (DM) intake. Dirksen et al. (1985) stated that the early-lactation cows are at a higher risk due to reduced absorptive capacity of the rumen, poorly adapted rumen microflora and the rapid introduction to high-energy dense diets. Oetzel (2005) observed that cows at peak DM intake are at an increased risk due to the greater amount of acids produced in the rumen. Regarding SARA diagnosis, Enemark (2008) stated that recent developments in technology have led to the use of indwelling rumen $\mathrm{pH}$ probes, the use of rumen valerate, and urinary net acid and base excretion.

Dairy cows' health needs to be monitored at the herd level. For that purpose test day records (TDRs) represent an alternative which is much more cost-effective and noninvasive when compared to specific diagnostics (Duffield et al., 1997; Eicher, 2004). TDRs include daily milk, fat and protein production, and the fat-to-protein ratio $(F / P$ ratio).
Gravert (1991) indicated that the ideal range for the $F / P$ ratio is $1-1.25$, while Duffield et al. (1997) set 1.33 as the upper margin. Haas and Hofírek (2004) reported that an $F / P$ ratio higher than 1.4 indicates energy deficiency and, if ketone bodies are present, subclinical ketosis. Richardt (2004) defined an $F / P$ ratio of 1.5 as a risk level for subclinical ketosis, while Eicher (2004) also took into account daily milk production in addition to the $F / P$ ratio as an indication of metabolic disorders (acidosis, ketosis).

The objectives of this study were to determine the metabolic disorder prevalence regarding the lactation stage and the effect of subclinical disorders on daily milk traits of Holstein cows using monthly test day records in Croatia.

\section{Materials and methods}

\subsection{Data}

The individual test day records collected in regular milk recordings in the period from January 2004 to December 2013 in Croatia were used for analysis. Milk recording was performed according to the alternative milk recording method (AT4/BT4), meaning monthly measurements of milk yield during the evening or morning milkings and milk sampling from each lactating cow. The daily milk yield and fat content were projected from the partial measurement. The logical control of milk data was performed according to International Committee for Animal Recording (ICAR) standards (2003). Daily milk trait variability regarding the parity is shown in Table 1 . Records with lactation stages at $<0$ and $>305$ days, missing or no parity, test date, owner and region value were deleted from the dataset. After logical control, data consisted of 1962831 test day records of milk, fat and protein from 130104 Holsteins reared on 9201 farms in Croatia. According to parity, four classes were formed: P1, P2, P3 and P4+. The last class included cows in the fourth and higher lactations. Regarding the lactation stage, 16 classes according to 5 days were formed: L1 $(<10) \ldots$ L16 (>90). Regarding the test date, month-year classes were formed. The metabolic disorder (ketosis or acidosis) prevalence was indicated by the $F / P$ ratio. $F / P \geq 1.5$ was taken 
as an indicator of ketosis prevalence, while $F / P<1.0$ was taken as an indicator of acidosis prevalence. The metabolic disorder prevalence was calculated as the frequency of cows indicated as being at risk in the total number of cows according to lactation stage classes and the parity class. Subclinical disorder (ketosis or acidosis) was indicated by the $F / P$ ratio and cows' daily production (Eicher, 2004). $F / P \geq 1.5$ in cows that yielded between 33 and $50 \mathrm{~kg} \mathrm{day}^{-1}$ was taken as an indicator of subclinical ketosis, while $F / P<1.0$ in cows that yielded between 20 to $43 \mathrm{~kg}_{\text {day }}{ }^{-1}$ was taken as an indicator of subclinical acidosis. Only cows with a detected subclinical disorder were included in the analyses. Milk traits measured on the test day when the subclinical disorder occurred were used as the reference level. The disorder index was defined as follows, according to the number of days after the subclinical disorder indication: D-0 - test day milk yields collected when subclinical disorder was indicated; A1 - yields collected within 35 days of indication; A-2 - yields collected between 35 and 70 days after indication; A-3 yields collected between 70 and 105 days after indication; and A-4 - yields collected more than 105 days after indication.

\subsection{Statistical analysis}

The effect of subclinical disorders (ketosis or acidosis) on daily milk traits was studied separately for each parity class using the following statistical model:

$$
\begin{aligned}
y_{i j k l m}= & \mu+b_{1}\left(\frac{d_{i}}{305}\right)+b_{2}\left(\frac{d_{i}}{305}\right)^{2}+b_{3} \ln \left(\frac{305}{d_{i}}\right) \\
& +b_{4} \ln ^{2}\left(\frac{305}{d_{i}}\right)+S_{j}+R_{k}+H_{l}+e_{i j k l m},
\end{aligned}
$$

where $y_{i j k l m}$ is the estimated daily milk trait; $\mu$ is the intercept; $b_{1}, b_{2}, b_{3}$ and $b_{4}$ are the regression coefficients; $H_{l}$ is the days in milk; $S_{j}$ is the fixed effect of month-year $j$ ( $j=1 / 2004$ to $12 / 2013) ; R_{k}$ is the fixed effect of region $k$ ( $k$ : Croatian counties); $D_{l}$ is the fixed effect of the disorder index $l(l=\mathrm{D}-0, \mathrm{~A}-1, \mathrm{~A}-2, \mathrm{~A}-3, \mathrm{~A}-4)$; and $e_{i j k l m}$ is the residual.

The significance of the differences between the levels of the disorder index was tested by Scheffe's method of multiple comparisons using the MIXED procedure of SAS (SAS Institute Inc., 2000).

\section{Results}

The ketosis prevalence indicated by the daily $F / P \geq 1.5$ was considered with regard to the lactation stage and parity (Fig. 1). In first-parity cows, the highest prevalence, with an indication in $33 \%$ of cows, occurred in the first 15 day of lactation, after which a continuous declining trend was noticed. The prevalence peak in cows in higher lactations occurred on 25th day of lactation, with the highest prevalence in cows in the third lactation. A similar declining trend after

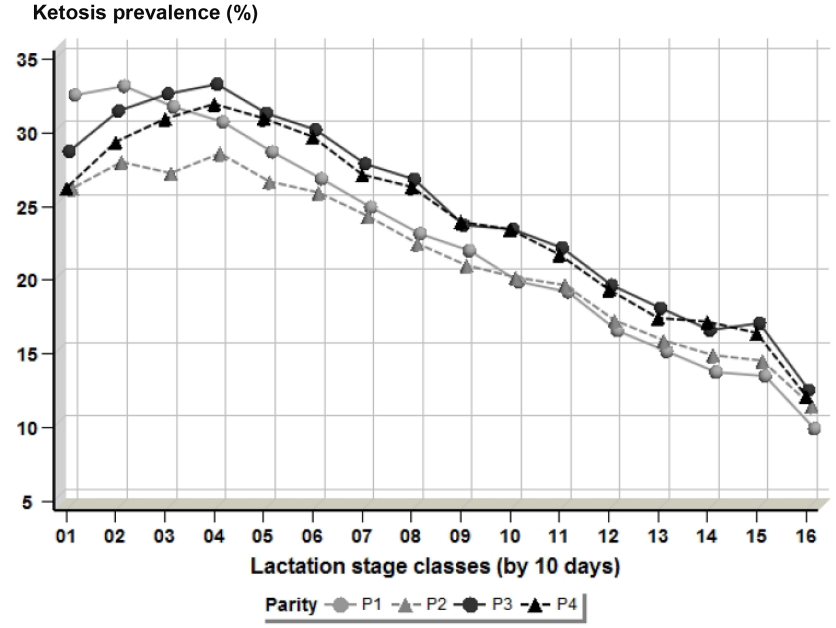

Figure 1. Ketosis prevalence (\%) according to lactation stage and parity classes.

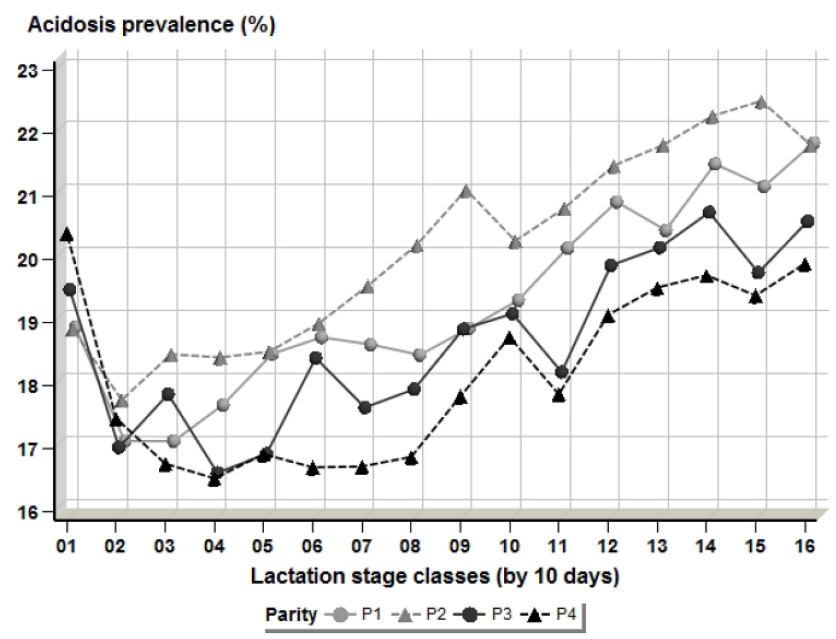

Figure 2. Acidosis prevalence (\%) according to lactation stage and parity classes.

the prevalence peak was noticed in first-parity cows and also characterized cows in higher lactations. The highest prevalence during all lactations, with the exception of the first 15 days, was observed in third-lactation cows.

The acidosis prevalence indicated by the daily $F / P<1.0$ was considered with regard to the lactation stage and parity (Fig. 2). A high prevalence, with an indication in 19 to $20.5 \%$ of cows, depending on parity, occurred in the first 10 days of lactation, after which the risk declined in the next 5 days. The prevalence increase was observed from the 15th lactation day in cows in first, second and third lactation, with the highest increase in second-lactation cows. In cows in fourth and higher lactations, the prevalence increase started after the 45th lactation day. 
Table 2. Effect of subclinical disorders (ketosis (KET), acidosis (ACI)) on daily milk traits according to parity.

\begin{tabular}{|c|c|c|c|c|c|c|c|c|}
\hline \multirow[t]{2}{*}{ Metabolic disorder index } & \multicolumn{2}{|c|}{ Parity 1} & \multicolumn{2}{|c|}{ Parity 2} & \multicolumn{2}{|c|}{ Parity 3} & \multicolumn{2}{|c|}{ Parity 4+ } \\
\hline & KET & ACI & KET & ACI & KET & ACI & KET & ACI \\
\hline \multicolumn{9}{|l|}{ Daily milk yield (kg) } \\
\hline D-0 & $33.98^{\mathrm{A}}$ & $25.72^{\mathrm{A}}$ & $33.45^{\mathrm{A}}$ & $26.16^{\mathrm{A}}$ & $33.75^{\mathrm{A}}$ & $26.26^{\mathrm{A}}$ & $32.40^{\mathrm{A}}$ & $24.74^{\mathrm{A}}$ \\
\hline A-1 & $29.74^{\mathrm{B}}$ & $24.32^{\mathrm{B}}$ & $30.72^{\mathrm{B}}$ & $25.06^{\mathrm{B}}$ & $30.96^{\mathrm{B}}$ & $25.08^{\mathrm{B}}$ & $27.61^{\mathrm{B}}$ & $23.00^{\mathrm{B}}$ \\
\hline A-2 & $28.92^{\mathrm{C}}$ & $24.26^{\mathrm{B}}$ & $29.61^{C}$ & $24.53^{\mathrm{C}}$ & $29.81^{\mathrm{C}}$ & $24.29^{\mathrm{C}}$ & $26.52^{\mathrm{C}}$ & $22.32^{\mathrm{C}}$ \\
\hline A-3 & $28.05^{\mathrm{D}}$ & $23.60^{\mathrm{C}}$ & $28.49^{\mathrm{D}}$ & $23.67^{\mathrm{D}}$ & $28.82^{\mathrm{D}}$ & $23.41^{\mathrm{D}}$ & $25.63^{\mathrm{D}}$ & $21.56^{\mathrm{D}}$ \\
\hline A-4 & $27.21^{\mathrm{E}}$ & $23.32^{\mathrm{D}}$ & $27.49^{\mathrm{E}}$ & $22.57^{\mathrm{E}}$ & $27.84^{\mathrm{E}}$ & $21.96^{\mathrm{E}}$ & $25.11^{\mathrm{D}}$ & $20.44^{\mathrm{E}}$ \\
\hline \multicolumn{9}{|l|}{ Daily fat content (\%) } \\
\hline D-0 & $5.21^{\mathrm{A}}$ & $2.84^{\mathrm{A}}$ & $5.20^{\mathrm{A}}$ & $2.87^{\mathrm{A}}$ & $5.12^{\mathrm{A}}$ & $2.84^{\mathrm{A}}$ & $5.14^{\mathrm{A}}$ & $2.87^{\mathrm{A}}$ \\
\hline A-1 & $4.17^{\mathrm{B}}$ & $3.65^{\mathrm{B}}$ & $4.23^{\mathrm{B}}$ & $3.73^{\mathrm{B}}$ & $4.18^{\mathrm{B}}$ & $3.77^{\mathrm{B}}$ & $4.17^{\mathrm{B}}$ & $3.90^{\mathrm{B}}$ \\
\hline A-2 & $4.16^{\mathrm{B}}$ & $3.59^{\mathrm{C}}$ & $4.24^{\mathrm{B}}$ & $3.69^{\mathrm{B}}$ & $4.18^{\mathrm{B}}$ & $3.71^{\mathrm{C}}$ & $4.20^{\mathrm{B}}$ & $3.85^{\mathrm{C}}$ \\
\hline A-3 & $4.12^{\mathrm{B}}$ & $3.66^{\mathrm{B}}$ & $4.19^{\mathrm{C}}$ & $3.76^{\mathrm{B}}$ & $4.12^{\mathrm{B}}$ & $3.80^{\mathrm{B}}$ & $4.17^{\mathrm{B}}$ & $3.88^{\mathrm{C}}$ \\
\hline A-4 & $4.13^{\mathrm{B}}$ & $3.63^{\mathrm{D}}$ & $4.24^{\mathrm{B}}$ & $3.73^{\mathrm{B}}$ & $4.15^{\mathrm{B}}$ & $3.77^{\mathrm{B}}$ & $4.21^{\mathrm{B}}$ & $3.82^{\mathrm{D}}$ \\
\hline \multicolumn{9}{|l|}{ Daily protein content (\%) } \\
\hline D-0 & $3.14^{\mathrm{A}}$ & $3.35^{\mathrm{A}}$ & $3.20^{\mathrm{A}}$ & $3.36^{\mathrm{A}}$ & $3.16^{\mathrm{A}}$ & $3.32^{\mathrm{A}}$ & $3.15^{\mathrm{A}}$ & $3.33^{\mathrm{A}}$ \\
\hline A-1 & $3.22^{\mathrm{B}}$ & $3.31^{\mathrm{B}}$ & $3.27^{\mathrm{B}}$ & $3.33^{\mathrm{B}}$ & $3.21^{\mathrm{B}}$ & $3.29^{\mathrm{B}}$ & $3.23^{\mathrm{B}}$ & $3.27^{\mathrm{B}}$ \\
\hline A-2 & $3.25^{\mathrm{B}}$ & $3.31^{\mathrm{B}}$ & $3.31^{\mathrm{C}}$ & $3.33^{\mathrm{B}}$ & $3.26^{\mathrm{C}}$ & $3.30^{\mathrm{B}}$ & $3.26^{\mathrm{C}}$ & $3.27^{\mathrm{B}}$ \\
\hline A-3 & $3.27^{\mathrm{C}}$ & $3.32^{\mathrm{B}}$ & $3.33^{\mathrm{D}}$ & $3.34^{\mathrm{B}}$ & $3.27^{\mathrm{C}}$ & $3.31^{\mathrm{A}}$ & $3.28^{\mathrm{C}}$ & $3.28^{\mathrm{B}}$ \\
\hline A-4 & $3.31^{\mathrm{D}}$ & $3.32^{\mathrm{B}}$ & $3.35^{\mathrm{E}}$ & $3.34^{\mathrm{B}}$ & $3.29^{\mathrm{C}}$ & $3.32^{\mathrm{A}}$ & $3.28^{\mathrm{C}}$ & $3.27^{\mathrm{B}}$ \\
\hline \multicolumn{9}{|l|}{ Fat / protein } \\
\hline D-0 & $1.68^{\mathrm{A}}$ & $0.84^{\mathrm{A}}$ & $1.65^{\mathrm{A}}$ & $0.85^{\mathrm{A}}$ & $1.65^{\mathrm{A}}$ & $0.85^{\mathrm{A}}$ & $1.66^{\mathrm{A}}$ & $0.85^{\mathrm{A}}$ \\
\hline A-1 & $1.30^{\mathrm{B}}$ & $1.10^{\mathrm{B}}$ & $1.30^{\mathrm{B}}$ & $1.12^{\mathrm{B}}$ & $1.31^{\mathrm{B}}$ & $1.15^{\mathrm{B}}$ & $1.30^{\mathrm{B}}$ & $1.20^{\mathrm{B}}$ \\
\hline A-2 & $1.29^{\mathrm{B}}$ & $1.09^{\mathrm{B}}$ & $1.29^{\mathrm{B}}$ & $1.11^{\mathrm{B}}$ & $1.29^{\mathrm{B}}$ & $1.13^{\mathrm{C}}$ & $1.30^{\mathrm{B}}$ & $1.19^{\mathrm{B}}$ \\
\hline A-3 & $1.27^{\mathrm{C}}$ & $1.11^{\mathrm{B}}$ & $1.27^{\mathrm{C}}$ & $1.13^{\mathrm{B}}$ & $1.27^{\mathrm{C}}$ & $1.15^{\mathrm{B}}$ & $1.28^{\mathrm{B}}$ & $1.19^{\mathrm{B}}$ \\
\hline A-4 & $1.26^{\mathrm{C}}$ & $1.09^{\mathrm{B}}$ & $1.26^{\mathrm{C}}$ & $1.12^{\mathrm{B}}$ & $1.27^{\mathrm{C}}$ & $1.14^{\mathrm{B}}$ & $1.29^{\mathrm{B}}$ & $1.17^{\mathrm{C}}$ \\
\hline
\end{tabular}

Values within the same column marked with different letters differ in a statistically highly significant way $(p<0.01)$.

The effect of subclinical disorders (ketosis, acidosis) on daily milk traits indicated by the $F / P$ ratio and daily milk yield was evaluated for each parity class (Table 2). All traits included in the statistical model were shown to be highly significant $(p<0.01)$. A significant negative effect of subclinical ketosis on daily milk yield for each parity was determined (Table 2). A decrease in milk yield of 4.21, 2.73, 2.78, 2.83 and $3.72 \mathrm{~kg} \mathrm{day}^{-1}$ in each parity (i.e., parities $1,2,3$ and $4+$ ) was determined within 35 days after the detection of subclinical ketosis. The milk-reducing effect continued in subsequent milk controls.

A highly significant decrease in daily fat content, a highly significant increase in daily protein content and an expected highly significant drop in the $F / P$ ratio were observed within 35 days of the subclinical ketosis indication date in all parity classes. Regarding the subclinical acidosis detection, a significant negative effect was determined on the daily milk yield as well as on the daily protein content regardless of the parity. The daily milk yield decreased within 35 days after the subclinical acidosis detection date, with 1.4, 1.1, 2.79 and $1.74 \mathrm{~kg} \mathrm{day}^{-1}$ in parity class $1,2,3$ and $4+$. A production decline in subsequent milk controls in all cows was also determined. As a consequence of subclinical acidosis, the daily fat content significantly increased by about $1 \%$ day $^{-1}$. This increase was retained in subsequent milk controls. Due to subclinical acidosis incidence, the daily protein content significantly decreased, while the $F / P$ ratio, as expected, significantly increased. Determined trends apply for all parity classes.

\section{Discussion}

The majority of metabolic disorder cases occurs at the beginning of lactation when the physiological demands of the cow are high. Mulligan and Doherty (2008) defined the period 3 weeks before and 3 weeks after calving as the critical period associated with a peak incidence of metabolic and nutritional disorders or infectious diseases. These disorders and diseases have been generally associated with increased un- 
planned culling, which leads to financial loses (Fetrow et al., 2006) by increasing diagnosis and treatment costs and decreasing milk yield and reproductive performance in a dairy herd (Suthar et al., 2013). Due to a negative energy balance at the beginning of lactation, the milk fat content tends to increase, while the milk protein content tends to decrease, which makes the $F / P$ ratio a good indicator in metabolic disorder detection. According to Heuer et al. (1999), the first test day records (daily milk yield and $F / P$ ratio) are a more reliable predictor of disorders, fertility and milk yield than a loss in body condition scoring. Therefore, the determination of subclinical ketosis (SCK) prevalence based on the $F / P$ ratio during the first 2 weeks of lactation could be beneficial (Iwersen et al., 2009). Suthar et al. (2013) stated that the prevalence of SCK was high between 2 to 15 days in milk. This high prevalence increased the odds of metritis, clinical ketosis, lameness and a displaced abomasum in European dairy herds. Koeck et al. (2013) stated that $87 \%$ of ketosis cases in Holstein cows was recorded during the first 30 days of lactation. The results of this study confirm that the highest ketosis prevalence occurred in early lactation. In the first-parity cows, ketosis prevalence was highest in the first 15 days of lactation, while in cows in higher lactations, the prevalence peak occurred on the 25th day. A higher ketosis prevalence during the entire lactation was observed in multiparous cows compared to first-parity cows, with the exception of the first 15 days of lactation. Similarly, McArt et al. (2012) reported the lowest ketosis prevalence in first-parity cows. A more frequent ketosis prevalence in multiparous cows compared with primiparous cows was also observed by Carrier et al. (2004), while Andersson and Emanuelson (1985) and Duffield et al. (1997) concluded that levels of ketosis increase with parity. In this study, a ketosis prevalence higher than $30 \%$ was determined in the first month of lactation in all cows, regardless of the parity. Similarly, like previous research (Dirksen et al., 1985; Bramley et al., 2005; Oetzel, 2005; O'Grady et al., 2008), this study showed a high acidosis prevalence at the beginning of lactation (19-20.5\% of cows depending on the parity), with a decreasing trend until mid-lactation, when prevalence increased up to $22 \%$. Toni et al. (2011) found that cows with an $F / P$ ratio in the interval $(<1 ;>2)$ showed consistently lower milk production. According to Rajala-Schultz et al. (1999), the average total loss per cow due to ketosis prevalence was over $300 \mathrm{~kg}_{\text {lactation }}{ }^{-1}$, while McArt et al. (2012) determined that cows with subclinical ketosis, compared to non-ketotic cows, produce 3.4-6\% less milk daily in the first 30 days of lactation. Significantly lower milk production in the first month of lactation was confirmed by McArt et al. (2013) in later research as well as by Ospina et al. (2010). A significant $(p<0.01)$ decrease in daily milk yield as well as daily fat content within 35 days of the subclinical ketosis detection date was also determined in this research. The highest decrease in daily milk yield was determined in first-parity cows and cows with more than four lactations; the decrease amounted to 4.21 and $3.72 \mathrm{~kg} \mathrm{day}^{-1}$, respectively. The milk-reducing effect continued in subsequent milk controls. A significant negative effect of subclinical acidosis was also determined. The highest drop in daily milk yield of $2.79 \mathrm{~kg} \mathrm{day}^{-1}$ within the 35 days after the subclinical acidosis detection date was determined in cows in the third lactation. A production decline in subsequent milk controls in all cows was also determined. As a consequence of subclinical acidosis, the daily fat content significantly increased by about $1 \%$ day $^{-1}$, while the daily protein content significantly decreased.

As the results of this study show, a significant decrease in daily milk quantity and variation of daily milk quality in Holsteins could be expected in cases when the $F / P$ ratio $\geq 1.5$ in cows that yielded between 33 and $50 \mathrm{~kg} \mathrm{day}^{-1}$ (subclinical ketosis) as well as when $F / P<1.0$ in cows that yielded between 20 and $43 \mathrm{~kg} \mathrm{day}^{-1}$ (subclinical acidosis). Also, a production decline in subsequent milk controls after the detection of both disorders could be expected.

\section{Conclusions}

Late pregnancy and early lactation is the most critical period for high-producing cows associated with a peak metabolic disorder prevalence. Generally, metabolic disorder prevalence has been associated with high financial losses due to increased treatment costs, decreased milk production, impaired reproduction efficiency and increased involuntary culling. This study determined a highly significant decline in daily milk yield and variation of daily milk components as a result of metabolic disorders (ketosis or acidosis) detected based on the fat / protein ratio and daily milk yield. This indicates that the $F / P$ ratio could be a good indicator of metabolic disorder prevalence, while the $F / P$ ratio associated with daily milk yield could be an accurate indicator in metabolic disorder detection. Finally, test day records could be used as a cost-effective and non-invasive method for monitoring herd health, enabling the farmer to react early and prevent the development of strong clinical symptoms. In this way, the farmer's economic losses and the cow's illness could be significantly decreased or completely avoided.

\section{Data availability}

Analysed databace are not publicly accessible because this is national database which is available only with the approval of the director of the Croatian Agricultural Agency.

Acknowledgements. Acknowledgements to the Croatian Agricultural Agency for access to the necessary database.

Edited by: S. Maak

Reviewed by: M. Brka, A. Kostelic, and one anonymous referee 


\section{References}

Andersson, L.: Subclinical ketosis in dairy cows, Metabolic diseases of ruminant livestock, Vet. Clin. North Am. Food Anim. Pract., 4, 233-251, 1988.

Andersson, L. and Emanuelson, U.: An epidemiological study of hyperketonaemia in Swedish dairy cows; determinants and the relation to fertility, Prev. Vet. Med., 3, 449-462, 1985.

Bramley, E., Lean, I. J., Costa, N. D., and Fulkerson, W. J.: Acidosis in pasture fed dairy cows: risk factors and outcomes, 2005 Joint Annual Meetin, Cincinnati, Ohio, USA, 24-28 July 2005, J. Dairy Sci., 88, 2005.

Broucek, J., Ryba, S., Mihina, S., Uhrincat, M., and Kisac, P.: Impact of thermal-humidity index on milk yield under conditions of different dairy management, J. Anim. Feed Sci., 16, 329-344, 2007.

Carrier, J., Stewart, S., Godden, S., Fetrow, J., and Rapnicki, P.: Evaluation and use of three cowside tests for detection of subclinical ketosis in early postpartum cows, J. Dairy Sci., 87, 37253735, 2004.

Dirksen, G., Liebich, H., and Mayer, H.: Adaptive changes of the ruminal mucosa and functional and clinical significance, Bovine Practice, 20, 116-120, 1985.

Dohoo, I. R. and Martin, S. W.: Subclinical ketosis: prevalence and associations with production and disease, Can. J. Comp. Med., 48, 1-5, 1984.

Duffield, T. F., Kelton, D. F., Leslie, K. E., Lissemore, K. D., and Lumsden, J. H.: Use of test day milk fat and milk protein to detect subclinical ketosis in dairy cattle in Ontario, Can. Vet. J., 38, 713-718, 1997.

Eicher R.: Evaluation of the metabolic and nutritional situation in dairy herds: Diagnostic use of milk components, 23rd World Buiatrics Congress, Québec, Canada, 11-16 July, 2004.

Enemark, J. M. D.: The monitoring, prevention and treatment of subacute ruminal acidosis (SARA) - a review, Vet. J., 176, 3234, 2008.

Fetrow, J., Nordlund, K. V., and Norman, H. D.: Invited review: Culling: Nomenclature, definitions, and recommendations, J. Dairy Sci., 89, 1896-1905, 2006.

Gillund, P., Reksen, O., Gröhn, Y. T., and Karlberg, K.: Body condition related to ketosis and reproductive performance in Norwegian dairy cows, J. Dairy Sci., 84, 1390-1396, 2001.

Gravert, H. O.: Indicators for assessment of energy balance in highyielding cows, Monatsh Veterinarmed, 46, 536-537, 1991.

Gustafsson A. H. and Emanuelson U.: Milk acetone concentration as an indicator of hyperketonaemia in dairy cows: The critical value revised, Anim. Sci., 63, 183-188, 1996.

Haas, D. and Hofírek, B.: The diagnostic importance of milk components for a human and cows' health, CUA Prague, Proceedings of contributions: Milk day, 26-29, 2004.

Heuer, C., Schukken, Y. H., and Dobbelaar, P.: Postpartum bodycondition score and results from the first test day milk as predictorsof disease, fertility, yield, and culling in commercial dairyherds. J. Dairy Sci., 82, 295-304, 1999.
ICAR - International Committee for Animal Recording: Guidelines approved by the General Assembly held in Interlaken, Switzerland, on 30 May 2002, Roma, 19-39, 2003.

Iwersen, M., Falkenberg, U., Voigtsberger, R., Forderung, D., and Heuwieser, W.: Evaluation of an electronic cowside test to detect subclinical ketosis in dairy cows, J. Dairy Sci., 92, 2618-2624, 2009.

Koeck, A., Miglior, F., Jamrozik, J., Kelton, D. F., and Schenkel, F. S.: Genetic associations of ketosis and displaced abomasum with milk production traits in early first lactation of Canadian Holsteins, J. Dairy Sci., 96, 4688-4696, 2013.

LeBlanc, S.: Monitoring metabolic health of dairy cattle in the transition period, J. Reprod. Dev., 56, S29-S35, 2010.

McArt, J. A., Nydam, D. V., and Oetzel, G. R. Epidemiology of subclinical ketosis in early lactation dairy cattle, J. Dairy Sci., 95, 5056-5066, 2012.

McArt, J. A., Nydam, D. V., and Oetzel, G. R.: Dry period and parturient predictors of early lactation hyperketonemia in dairy cattle, J. Dairy Sci., 96, 198-209, 2013.

Mulligan, F. J. and Doherty, M. L.: Production diseases of the transition cow, Vet. J., 176, 3-9, 2008.

Oetzel, G. R.: Applied aspects of ruminal acidosis induction and prevention, J. Dairy Sci., 88, 643, 2005.

O'Grady, L., Doherty, M. L., and Mulligan, F. J.: Subacute ruminal acidosis (SARA) in grazing dairy cows, Vet. J., 176, 44-49, 2008.

Ospina, P. A., Nydam, D. V., Stokol, T., and Overton, T. R.: Association between the proportion of sampled transition cows with increased nonesterified fatty acids and $\beta$-hydroxybutyrate and disease incidence, pregnancy rate, and milk production at the herd level, J. Dairy Sci., 93, 3595-3601, 2010.

Rajala-Schultz, P. J. and Gröhn, Y. T.: Effects of dystocia, retained placenta, and metritis on milk yield in dairy cows, J. Dairy Sci., 81, 3172-3181, 1998.

Rajala-Schultz, P. J., Grohn, Y. T., and McCulloch, C. E.: Effects of milk fever, ketosis, and lameness on milk yield in dairy cows, J. Dairy Sci., 82, 288-294, 1999.

Richardt, W.: Milk composition as an indicator of nutrition and health, The Breeding, 11, 26-27, 2004.

SAS User's Guide: Version 8.2 Edition, SAS Institute Inc., Cary, NC, 2000.

Suthar, V. S., Canelas-Raposo, J., Deniz, A., and Heuwieser, W.: Prevalence of subclinical ketosisand relationships with postpartum diseases in European dairy cows, J. Dairy Sci., 96, 29252938, 2013.

Toni, F., Vincenti, L., Grigoletto, L., Ricci, A., and Schukken, Y. H.: Early lactation ratio of fat and protein percentage in milk is associated with health, milk production, and survival, J. Dairy Sci., 94, 1772-1783, 2011. 